\title{
Variation of Phenolic and Pigment Composition Depending on Soil Type in Three Serpentinovag Plant Species
}

\author{
Fazilet Ozlem Albayrak ${ }^{\circledR 1}$, Ebru Ozdeniz ${ }^{\circledR 2}$, Latif Kurt ${ }^{\circledR 2}$, Yuksel Keles ${ }^{\left({ }^{\circledR} \text {,* }\right.}$
}

\author{
${ }^{1}$ Department of Biology, Faculty of Art and Science, Aksaray University, Aksaray, Turkey \\ ${ }^{2}$ Department of Biology, Faculty of Science, Ankara University, Ankara, Turkey \\ ${ }^{3}$ Department of Science, Faculty of Education, Mersin University, Mersin, Turkey
}

\begin{abstract}
Serpentine soils are stressful for plant growth, due to nutrient deficiencies, especially $\mathrm{Ca}$, low water-holding capacity, and high levels of heavy metals and $\mathrm{Mg}$. Determination of biochemical differences of plants grown in serpentine and non-serpentine soil can contribute to understanding tolerance to serpentine soil. In this study, samples of three plant species (Alyssum sibiricum Willd., Salvia absconditiflora (Montbret \& Aucher ex Bentham) Greuter \& Burdet and Centaurea urvillei DC. subsp. stepposa Wagenitz) were compared in terms of the composition of phenolic compounds and chloroplast pigments. Higher amounts of phenolic compounds were measured in serpentine soil-grown forms of all three species. Total soluble phenolic content, in samples grown in serpentine and non-serpentine soil, respectively, S. absconditiflora 731.8 - 161.7, C. urvillei 121.0-49.7 and A. sibiricum 50.2- $\left.47.3 \mu \mathrm{g} \mathrm{g}^{-1} \mathrm{DW}\right)$. It was determined that the amount of chlorophyll a was higher in the serpentine soil grown forms of all three species while the amount of chlorophyll b was variable. In plants grown in serpentine soil, $\beta$-carotene values are higher than non-serpentine forms. Total xanthophyl values are also parallel with $\beta$-carotene findings, but lower. The findings in the present study show that antioxidant compounds such as phenolics and carotenoids may play a role in the stress tolerance of plants growing in serpentine habitats.
\end{abstract}

\section{ARTICLE HISTORY}

Received: July 07, 2020

Revised: November 10, 2020

Accepted: February 19, 2021

\section{KEYWORDS}

Carotenoid,

Chlorophyll,

Phenolic compounds,

Serpentine stress

\section{INTRODUCTION}

Serpentine soils are model systems for the study of evolution, ecology, and conservation (Harrison \& Rajakaruna, 2011). Serpentine soils are stressful for plant growth, due to nutrient deficiencies, especially $\mathrm{Ca}$, low water-holding capacity, and high levels of heavy metals and $\mathrm{Mg}$ (Kruckeberg, 1951). Serpentine soils as a product of ultramafic rocks formed of ferromagnesian silicates are extremely rich in terms of floristic diversity, particularly of endemic and rare taxa. High content of $\mathrm{Mg}$ and $\mathrm{Fe}$ and low $\mathrm{Ca}$ in serpentine soils are not suitable for plants growth and development thereon. Serpentine soils, although rich in heavy metals such as $\mathrm{Ni}, \mathrm{Co}$, and $\mathrm{Cr}$, are poor in certain basic nutrients such as $\mathrm{N}, \mathrm{P}$, and $\mathrm{K}$ (Avc1, 2005).

Plants adapting to serpentine soil systems, those being essential serpentine plants, namely obligate ones, and not being able to go out of serpentine, are named as serpentinophyte, and

CONTACT: Yuksel Keles $\square$ ykeles@mersin.edu.tr $\equiv$ Department of Science, Faculty of Education, Mersin University, Mersin, Turkey 
those able to grow facultatively under different edaphic conditions, both serpentine and nonserpentine, as serpentinovag (Kurt et al., 2013). Arnold et al. (2016) genetically studied the serpentine soil adapted population of Arabidopsis arenosa (L.) Lawalrée to understand how plants recover from the combination of mineral deficiency, drought and toxic metal levels seen in serpentine habitats. Ultimately, they reported that genes that contributed to drought adaptation were selected.

The experimental results showed that serpentine plants do better on nonserpentine soils than on serpentine soils. Performance of putative soil-specific ecotypes of two plant species (Achillea borealis Bong. and Gilia capitata Sims.) when grown on nonserpentine and serpentine soils in the greenhouse (Kruckeberg, 1951). Kruckeberg (1951) has achieved three conclusions on plant endemism in serpentine soils: (1) plants are locally adapted to serpentine soils, forming distinct soil ecotypes; (2) soil ecotypes are the first stage in the evolutionary progression toward serpentine endemism; and (3) serpentine endemics are restricted from more fertile nonserpentine soils by competition (Anacker, 2014).

Secondary metabolites are commonly found in plants adapted to special ecosystems and different soil types. Adaptation to special conditions changes not only the morphological properties of plants, but also their biochemical composition (Cheynier et al., 2013). The accumulation and diversity of phenolic substances is an important factor in stress tolerance. Phenolic compounds provide tolerance to oxidative stress occurring under stress conditions due to their strong antioxidant properties (Agati et al., 2013). There are various studies manifesting accumulation of phenolic substances in plants under stress. Even though there is a linear relation between amount of phenolic substances and antioxidant capacity, antioxidant capacities of phenolic compounds vary. Caffeic acid and $p$-coumaric acid have especially higher antioxidant activities. Antioxidant capacity is related to side groups of phenolic ring (Kim \& Lee, 2004; Wojdylo et al., 2007).

One of the common stress symptoms in plants is the change in the amount of chloroplast pigments. Environmental stress factors such as drought, high temperature, lack of plant nutrients and heavy metal pollution cause chlorophyll loss (Öncel et al., 2000). Carotenoids, on the other hand, are more resistant to stress conditions with their antioxidant properties (Ramel et al., 2012). Carotenoid amounts can remain constant or increase under stress conditions. As a result of stress conditions affecting the two photosystems differently, the chlorophyll a / b ratio may vary. Increasing carotenoid / chlorophyll ratios may be a stress indicator for plants (Oncel et al., 2004).

The elements of the antioxidant defense system are particularly emphasized because environmental stress conditions frequently trigger oxidative stress. In addition to total antioxidant capacity, basic antioxidant compounds such as phenolic compounds, carotenoids and chlorophyll content important indicators of oxidative stress, have been analyzed. Our research findings could contribute to understanding whether there are any differences in antioxidant substance compositions of plants under stressful conditions of serpentine soils. Samples of three serpentinovag plant species that spread naturally in the serpentine regions of Central Anatolia were taken from altitudes of 850-1400 m. The steppe vegetation is dominant in this region of Central Anatolia. A characteristic continental climate prevails in the region, with rather cold winter and hot summer periods. Freezing in winter and drying in summer creates conditions not suitable for plants. The harsh climate conditions combined with the high metal levels of serpentine soils and the negativities caused by the insufficiency of plant nutrients make plant life difficult. The steppe plants that have adapted to living in the region are drought tolerant plants originating from the Iran-Turan biogeographical region. Data from the Ankara meteorological station show that the semi-arid continental climate is effective in the higher parts of the region and the Mediterranean climate in the lower parts (Akman, 2010). 
The genus Alyssum L. consists of 230 species that are native to Europe, Asia and Northern Africa. Species richness and diversity are confined to the Mediterranean and Turkey, and only a few species are distributed in North Africa, Central Asia, Siberia and North America (Li et al., 2014). Alyssum sibiricum Willd. It is a species that spreads naturally in Thrace, North, West and Central Anatolia, the Balkans, Crimea and the Caucasus, especially in slopes, steppe and open areas. Salvia L., with about 980 species and a nearly cosmopolitan distribution, is the largest genus in the angiosperm family Lamiaceae. The genus is represented by at least 500 species in Middle and South America, about 250 species in Southwest Asia and the Mediterranean region, and about 100 species in East Asia (Guo-Xiong et al., 2018). In Turkey, it is represented by more than 100 taxa. Salvia absconditiflora (Montbret \& Aucher ex Benth.) Greuter \& Burdet. It is a species that spreads on rocky limestone slopes, dry steppe, fallow fields, roadsides. The genus Centaurea L. spreads around the world with 750 species in Asia, North Africa, America and Europe (Nagaresh \& Rahiminejad, 2018). Turkey also has 255 taxa of the genus Centaurea and endemism rate is $66.8 \%$. Centaurea urvillei DC. subsp. stepposa Wagenitz spreads in Rocky slopes, macchie, open Pinus forests.

This study was planned to determine the role of phenolic and isoprenoid metabolism in serpentine soils adaptation of plants grown in natural environments. In this way, information can be provided on the biochemical regulation required for tolerance to stress conditions caused by serpentine soil properties. It is aimed to compare the three plant species grown in serpentine soils with the populations grown in non-serpentine soils. For this purpose, analysis of phenolic compounds and plastid pigments was carried out in the samples of three serpentinovag species growing in serpentine and non-serpentine soil. While HPLC procedure was followed in the analysis of phenolic compounds, TLC and spectrophotometric methods were used in the analysis of isoprenoids.

\section{MATERIAL and METHODS}

\subsection{Material}

Samples were taken from the different populations of the three plant species that were the subject of the study (Table 1), both in and without serpentine. Field studies were carried out in May and June in the Elmadağ and Imrahor walley, located in the south east of Ankara, in 2015 and 2016. The plants were identified using Flora of Turkey and The East Agean Islands, vol. 1, 5 and 7 (Davis, 1965, 1975, 1982) by Latif Kurt and plant samples are preserved in ANK herbarium. After the plants were brought to the laboratory, they were superficially cleaned and dried in a $60^{\circ} \mathrm{C}$ oven. For the analysis, only the aboveground parts of the plants consisting of leaf and herbaceous stem tissues were used. All analyzes were performed on samples from at least three different regions and average values are presented in the tables.

\subsection{Analyses of Phenolic Compounds}

Extraction of plant phenolic compounds and quantitative analysis with the help of HPLC were performed according to the method proposed by Caponio et al. (1999). $0.1 \mathrm{~g}$ sample taken from the above-ground parts of the plants was homogenized by breaking up in methanol. The homogenate was centrifuged at $10000 \mathrm{~g}$ for 10 minutes and the supernatant was filtered through $0.45 \mu \mathrm{m}$ cellulose acetate filters. $20 \mu \mathrm{L}$ volumes of the filtrates were injected into the HPLC column. Phenolic compounds contained in the standards and samples were separated by passing the reverse phase Supelco LC18 (size 250x4.6 $\mathrm{mm}$ and pore diameter $2.5 \mu \mathrm{m}$ ) through the column. As a mobile phase for separation, 2\% acetic acid (A) and methanol (B) solutions with a flow rate of $0.8 \mathrm{~mL} \mathrm{~min}^{-1}$. It was used with the gradient flow program determined by Caponio et al. (1999). The phenolic compound content in the samples was determined with a UV detector at $278 \mathrm{~nm}$. A mixture containing a total of 15 different phenolic compounds was used as standard. (benzoic acid, chlorogenic acid, caffeic acid, catechin, epicatechin, gallic acid, 
hesperidin, hydroxybenzoic acid, p-coumaric acid, quercetin, rosmarinic acid, sinapic acid, syringic acid, $t$-cinnamic acid, $t$-ferulic acid). Area measurements of the peaks obtained with the standard series were made and standard curves were created. The peaks of the phenolic compounds in the plant extract were compared with the standard peaks and their quantities were calculated.

Table 1. The plant species subject to the study, their families and their soil characteristics.

\begin{tabular}{|c|c|c|c|c|}
\hline Code & Species & Family & Soil type & $\begin{array}{l}\text { Locality, Collector and } \\
\text { Number of plants }\end{array}$ \\
\hline As $(\mathrm{S})$ & Alyssum sibiricum Willd. & Brassicaceae & On Serpantin & $\begin{array}{l}\text { Elmadağ Serpentine } \\
\text { Series, } 1350 \text { m., Kurt, L., } \\
12365\end{array}$ \\
\hline As (NS) & Alyssum sibiricum Willd. & & Non Serpantin & $\begin{array}{l}\text { Limestone slopes, Imrahor } \\
\text { valley, } 980 \text { m., Kurt, L., } \\
13427\end{array}$ \\
\hline $\mathrm{Sa}(\mathrm{S})$ & $\begin{array}{l}\text { Salvia absconditiflora (Montbret } \\
\text { \& Aucher ex Bentham) } \\
\text { Greuter \& Burdet }\end{array}$ & Lamiaceae & On Serpantin & $\begin{array}{l}\text { Elmadağ Serpentine } \\
\text { Series, } 1350 \text { m., Kurt, L., } \\
12370\end{array}$ \\
\hline $\mathrm{Sa}(\mathrm{NS})$ & $\begin{array}{l}\text { Salvia absconditiflora (Montbret } \\
\text { \& Aucher ex Bentham) } \\
\text { Greuter \& Burdet }\end{array}$ & & Non Serpantin & $\begin{array}{l}\text { Limestone slopes, Imrahor } \\
\text { valley, } 980 \text { m., Kurt, L., } \\
13452\end{array}$ \\
\hline $\mathrm{Cu}(\mathrm{S})$ & $\begin{array}{l}\text { Centaurea urvillei DC. subsp. } \\
\text { stepposa Wagenitz }\end{array}$ & Asteraceae & On Serpantin & $\begin{array}{l}\text { Elmadağ Serpentine } \\
\text { Series, } 1350 \text { m., Kurt, L., } \\
12342\end{array}$ \\
\hline $\mathrm{Cu}(\mathrm{NS})$ & $\begin{array}{l}\text { Centaurea urvillei DC. subsp. } \\
\text { stepposa Wagenitz }\end{array}$ & & Non Serpantin & $\begin{array}{l}\text { Limestone slopes, Imrahor } \\
\text { valley, } 980 \text { m., Kurt, L., } \\
13471\end{array}$ \\
\hline
\end{tabular}

\subsection{Analyses of Chlorophylls and Carotenoids}

Chlorophyll analyzes were made from $0.2 \mathrm{~g}$ tissues from dried plant leaves and herbaceous stem samples. The $\mathrm{pH}$ was adjusted to 7.8 for extraction and a cooled $80 \%$ acetone solution was used. Samples were crushed with $2 \times 4 \mathrm{~mL}$ solvent in pre-cooled mortars and transferred to centrifuge tubes. After centrifugation at $5000 \mathrm{~g}$ for 5 minutes, absorbance measurements were made with spectrophotometer at 664 and $647 \mathrm{~nm}$. Chlorophyll contents were calculated with equations determined by Porra et al. (1989). Analysis of carotenoids was performed by absorbance measurement in the spectrophotometer followed by separation by thin layer chromatography determined by Moore (1974). $0.2 \mathrm{~g}$ of dry leaves and herbaceous stem tissue were homogenized by breaking into $5 \mathrm{~mL}$ of cold acetone. The homogenate glass was filtered through fiber discs and taken into the rotary evaporator flasks and the solvent was completely evaporated at $50^{\circ} \mathrm{C}$. The residue was dissolved in $1 \mathrm{~mL}$ chloroform and taken into eppendorf tubes. $50 \mu \mathrm{L}$ portions of extracts and standards were applied to silica gel sheets (20 $\times 20,0.25 \mathrm{~mm}$ thickness). Hexane, diethyl ether, acetone, (60:30:20, v: v: v) mixture was used as mobile phase. The carotene and xanthophyll stains separated on the sheet were scraped separately and taken into the centrifuge tubes. It was shaken for 10 minutes by adding $5 \mathrm{~mL}$ of acetone, centrifuged for 5 minutes at $5000 \mathrm{~g}$ and absorbances at $450 \mathrm{~nm}$ were measured in the spectrophotometer. The amount of carotenoids was calculated with the help of curves drawn by $\beta$-carotene and lutein standards. 


\subsection{Statistical Analysis}

Analyses of phenolics and plastid pigments in the specimens pertaining to various populations collected from Ankara, Elmadağ and Imrahor walley regions were carried out in three repetitions. Analysis results were calculated as mean values for each species. The differences between the three serpentinovag species were evaluated with the Kruskal-Wallis test, and the differences between the different life strategies depending on the soil type were evaluated with the t-test.

\section{RESULTS and DISCUSSION}

The phenolic compounds were analyzed in three serpentinovag plant species grown in serpentine and non-serpentine soil. Higher amounts of phenolic compounds were measured in serpentine soil-grown forms of all three species. This difference is particularly high in $C$. urvillei and S. absconditiflora species. Although there are high amounts of phenolic substances in both forms of $S$. absconditiflora species, it was determined that especially the forms grown in serpentine soil are rich in coumaric acid $\left(484.3 \mu \mathrm{g} \mathrm{g}^{-1}\right)$ and chlorogenic acid $\left(186.6 \mu \mathrm{g} \mathrm{g}^{-1}\right)$ compounds. While in the serpentine soil-grown $S$. absconditiflora forms hesperidin $\left(22.2 \mu \mathrm{g} \mathrm{g}^{-}\right.$ $\left.{ }^{1}\right)$ was found, in non-serpentine soil-grown forms, a low amount of quersetin $\left(9.9 \mu \mathrm{g} \mathrm{g}^{-1}\right)$ and cinnamic acid $\left(2.4 \mu \mathrm{g} \mathrm{g}^{-1}\right)$ were determined. $C$. urvillei is the richest species in terms of phenolic substance diversity. Six different phenolic compounds were identified in the serpentine forms of $C$. urvillei and five in the non-serpentine forms. Of these compounds, except for cinnamic acid, others were measured in higher amounts in serpentine forms. Four different compounds were identified in the serpentine forms of the A. sibiricum species and three different compounds in the non-serpentine forms. Total phenolic content was higher in serpentine forms (Table 2).

Table 2. Phenolic substance compositions of three serpentinovag plant species. (serpentinovag on serpentine (S) and serpentinovag non serpentine (NS).

\begin{tabular}{lcccccc}
\hline Phenol & As $(\mathrm{S})$ & As $(\mathrm{NS})$ & $\mathrm{Sa}(\mathrm{S})$ & $\mathrm{Sa}(\mathrm{NS})$ & $\mathrm{Cu}(\mathrm{S})$ & $\mathrm{Cu}(\mathrm{NS})$ \\
\hline Compounds & - & - & $38.7 \pm 8.8$ & $40.6 \pm 8.1$ & - & - \\
\hline Benzoic acid & $29.3 \pm 20.1$ & $11.4 \pm 0.8$ & $186.6 \pm 11.7$ & $11.1 \pm 0.1$ & $21.7 \pm 8.8$ & $10.9 \pm 0.1$ \\
Chlorogenic acid & $12.5 \pm 4.4$ & $27.9 \pm 7.1$ & - & $2.4 \pm 0.2$ & $0.5 \pm 0.1$ & $7.9 \pm 1.2$ \\
Cinnamic acid & $2.9 \pm 0.2$ & $8.0 \pm 0.1$ & $484.3 \pm 97.2$ & $98.7 \pm 1.6$ & $18.1 \pm 0.1$ & $9.2 \pm 0.2$ \\
Coumeric acid & - & - & - & - & $15.7 \pm 5.4$ & $2.4 \pm 1.3$ \\
Epicatechin & - & - & $22.2 \pm 0.2$ & - & $64.0 \pm 0.3$ & $19.3 \pm 0.2$ \\
Hesperidin & $5.5 \pm 3.7$ & - & - & $9.9 \pm 1.8$ & $1.0 \pm 0.1$ & - \\
Quercetin & 50.2 & 47.3 & 731.8 & 162.7 & 121.0 & 49.7 \\
\hline Total & & & & &
\end{tabular}

Unit $\mu \mathrm{g} \mathrm{g}^{-1} \mathrm{DW}$.

Plants developed on serpentine are exposed to secondary water stress due to being exposed to high concentrations of heavy metals such as $\mathrm{Ni}, \mathrm{Co}$, and $\mathrm{Cr}$. High concentrations of heavy metals may damage roots leading to blocking water intake from soils. High concentrations of osmoprotectants such as soluble carbohydrates and proline have been determined in plants grown naturally in serpentine soil (Özbey et al., 2017). Studies on the effects of heavy metals such as $\mathrm{Ni}, \mathrm{Co}, \mathrm{Cr}$, which are abundant in serpentine soils, on plants have also reported similar findings (Öncel et al., 2000; Sharmila \& Pardha Saradhi, 2002). Stress conditions such as heavy metal (Petukhov et al., 2019), drought (Keleş \& Öncel, 2002) and nutrient deficiency (especially nitrogen and phosphorus) (Chishaki \& Horiguchi, 1997) can cause the accumulation of phenolic compounds. 
The researchers show that phenolic substance quantity is a suitable stress marker for many species, and they can increase under high temperature and drought conditions, particularly during summer times (Agati et al., 2013). Findings of the present study indicate that phenolic compounds are substantially high in quantity in all of the species examined (Table 2). A large number of plants naturally grown in high mountains and steppes were compared in terms of their phenolic content. However, no significant difference was found between the total soluble phenolic amounts of plants grown in these two different habitats. However, the highest phenolic substance values among the plants examined were determined in steppe plants such as Salvia sclarea L. and Xanthemum annuum L. (Oncel et al., 2004).

There is a strong correlation between the total amount of phenolic compounds and antioxidant capacity. The fact that the plants grown in serpentine soil has higher phenolic content may indicate that the serpentine stress has an oxidative property. There are studies showing that phenolic compounds and total antioxidant capacity are high in the members of the Lamiaceae family. In a study comparing Lamiacea and Poaceae species, it was determined that Lamiaceae species such as Salvia, Sideritis and Lamium were rich in phenolic compounds and antioxidant capacity (Sağır et al., 2018). Total phenolic substance content and antioxidant capacity of 112 anticancer medicinal plant species were analyzed utilizing methanolic and aqueous extracts. The findings proved that medicinal plants with higher content of total phenolic substances have substantially higher total antioxidant capacity. Based on these findings, it was suggested that phenolic compounds have substantial impact on antioxidant capacity of medicinal plants (Cai et al., 2004). Wojdylo et al. (2007) analyzed the relation between levels of phenolic compounds and antioxidant capacities in 32 herbaceous plants of various families, and they mentioned that there is a positive and significant correlation between phenolic compounds and antioxidant capacities. Gülcemal et al. (2010) reported that some phenolic glycosides contained in $C$. urvillei species can be used against cancer by their anti-proteosomal activities.

Chlorophyll and carotenoid compounds of three serpentinovag species subject to the study were analyzed. It was determined that the amount of chlorophyll a was higher in the serpentine soil grown forms of all three species while the amount of chlorophyll $b$ was variable. This situation, caused chlorophyll a / b ratios in the forms grown in serpentine soils to be higher than those grown in non-serpentine soil. While the average chlorophyll a / b ratio in serpentine forms was 2.21, it was calculated as 1.56 in non-serpentine forms. Among the three investigated species, the highest chlorophyll a value were determined as $S$. absconditiflora species. The species with the highest total carotenoid values is $S$. absconditiflora, $488 \mu \mathrm{g} \mathrm{g}^{-1}$ in serpentine forms and $457 \mu \mathrm{g} \mathrm{g}^{-1}$ in non-serpentine forms. It was determined that the amount of $\beta$-carotene of the species subject to the study is close to each other. In plants grown in serpentine soil, $\beta$ carotene values are higher than non-serpentine forms. Total xanthophyll values are also parallel with $\beta$-carotene findings, but lower. While the amount of carotenoid per chlorophyll was lower in the serpentine forms of the A. sibiricum species, it did not show a significant difference in the $C$. urvillei and S. absconditiflora species (Table 3).

One of the fastest observed stress indicators in plants is chlorophyll loss. There are many studies showing that it can cause chlorophyll loss in drought (Batra, Sharma \& Kumari, 2014), heavy metal stress (Öncel et al., 2000) and mineral nutrient deficiencies (Ruamrungsri et al., 1996). In this study, while chlorophyll a amount was found higher in serpentinovag species, in the forms grown in serpentine soils, a significant change in chlorophyll $b$ amount could not be determined. This may indicate the success of the three species studied in the adaptation of serpentine soils, as well as the forms grown in non-serpentine soils under the influence of various environmental stresses. The high rate of chlorophyll a / b in the forms grown in serpentine soils indicates that there is a difference in terms of regulation of photosystems. It is 
difficult to interpret the effect of serpentine on the amount of chlorophyll since there is not enough study on the physiological and biochemical adaptation of plants to serpentine habitats.

Carotenoids have critical importance in terms of protecting chloroplasts under stress conditions with their antioxidant properties. In the samples grown in serpentine soils of the three serpentinovag species subject to this study, both the amounts of $\beta$-carotene and xanthophylls were found to be significantly high. This indicates that the role of carotenoids should be studied in more detail in terms of tolerance to serpentine stress. Carotenoids protect chloroplasts against photoinhibition by dissipating excess energy under heat and light stress conditions (Choudhury \& Behera, 2001). It can be suggested that chloroplasts and photosynthetic structures of on-serpentine forms could be better protected against oxidative stress effects than non-serpentine forms. Çekiç et al. (2018), determined higher car/chl ratios in gypsophile plants adapted to gypsum soil. However, in gypsovag plants, a significant change from the soil type could not be identified.

Although there are some studies on the distribution, properties, ecology and plant endemism of serpentine soils (Brady et al., 2005; Kurt et al., 2013; Anacker, 2014) studies on the physiology and biochemistry of serpentine tolerance in plants are insufficient (Özbey et al., 2017). Determining the effects of serpentine stress on secondary metabolism in wild plants may contribute to the understanding of serpentine tolerance. In the three serpentinovag plant species that are the subject of this study, it has been determined that not only the amount but also the variety of the phenolic compounds varies depending on the soil properties. Similarly, changes in the amount and rates of isoprenoids (chlorophyll, $\beta$-carotene and xanthophylls) have been found.

Table 3. Pigment compositions of three serpentinovag species. (serpentinovag on serpentine (S) and serpentinovag non serpentine (NS).

\begin{tabular}{lcccccc}
\hline Species (soil type) & $\begin{array}{c}\text { Chl-a } \\
\left(\mu \mathrm{g} \mathrm{g}^{-1} \mathrm{DW}\right)\end{array}$ & $\begin{array}{c}\text { Chl-b } \\
\left(\mu \mathrm{g} \mathrm{g}^{-1} \mathrm{DW}\right)\end{array}$ & $\begin{array}{c}\text { Chl a/b } \\
\text { A. sibiricum (S) }\end{array}$ & $\begin{array}{c}\beta \text {-Carotene } \\
\left(\mu \mathrm{g} \mathrm{g}^{-1} \mathrm{DW}\right)\end{array}$ & $\begin{array}{c}\text { Xanthophyll } \\
\left(\mu \mathrm{g} \mathrm{g}^{-1} \mathrm{DW}\right)\end{array}$ & Car / Chl \\
A. sibiricum (NS) & $346 \pm 24$ & 1.98 & $265 \pm 37$ & $123 \pm 31$ & 0.38 \\
S. absconditiflora (S) & $389 \pm 34$ & $269 \pm 26$ & 1,44 & $228 \pm 32$ & $106 \pm 23$ & 0.51 \\
S. absconditiflora (NS) & $709 \pm 53$ & $368 \pm 25$ & 1,92 & $253 \pm 41$ & $204 \pm 34$ & 0.42 \\
C. urvillei (S) & $561 \pm 23$ & $274 \pm 22$ & 2.04 & $246 \pm 38$ & $111 \pm 15$ & 0.43 \\
C. urvillei (NS) & $473 \pm 37$ & $355 \pm 23$ & 1.33 & $235 \pm 46$ & $106 \pm 25$ & 0.41 \\
\hline Statistics: Species (KW) & $10.38(* *)$ & $5.46(\mathrm{~ns})$ & $4.85(\mathrm{~ns})$ & $7.30(\mathrm{~ns})$ & $10.38(* *)$ & $3.62(\mathrm{~ns})$ \\
\multicolumn{1}{c}{ Soil type (t) } & $0.00(* *)$ & $0.60(\mathrm{~ns})$ & $0.00(* *)$ & $0.00(* *)$ & $0.00(* *)$ & $0.09(\mathrm{~ns})$ \\
\hline
\end{tabular}

Kruskal-Wallis (KW) and t-test (t) results are shown at the bottom of each column (ns not significant, ${ }^{*} p \leq 0.05,{ }^{* *} p \leq 0.01$ ).

\section{CONCLUSION}

The findings in the present study show that antioxidant compounds such as phenolics and carotenoids may play a role in stress adaptation of plants growing in serpentin soils. In addition, it was concluded that serpentinovag plant species do not have common properties in terms of phenolic substance compositions, and show unique differences for each species. In serpentinegrown forms, the increase of antioxidants such as $\beta$-carotene and xanthophyll in addition to phenolic compounds can be attributed to the need for protection against oxidative stress. The findings of this research have shown that serpentine soils cause an increase in the phenolic substance content. However, it is not clear enough whether the variety of phenolic compounds synthesized in plants varies depending on the soil properties. For example, benzoic acid, chlorogenic acid and coumaric acid compounds were determined in both soil types, while the 
presence of cinnamic acid, quersetin and hesperidin compounds varied depending on the soil type. This subject is important for understanding phenolic metabolism under stress conditions and needs to be studied with more species.

\section{Declaration of Conflicting Interests and Ethics}

The authors declare no conflict of interest. This research study complies with research publishing ethics. The scientific and legal responsibility for manuscripts published in IJSM belongs to the author(s).

\section{Authorship contribution statement}

Fazilet Ozlem Albayrak: HPLC analysis of phenolic compounds. Ebru Ozdeniz: Collection of plant material from the field and preparation for analysis. Latif Kurt: Planning the study, identification of plant material and writing of the article. Yuksel Keles: Planning the study, analysis of isoprenoid compounds, writing of the article.

\section{Orcid}

Fazilet Ozlem Albayrak (D) https://orcid.org/0000-0002-5434-0081

Ebru Ozdeniz (D) https://orcid.org/0000-0003-4082-3071

Latif Kurt (i) https://orcid.org/0000-0001-9096-3895

Yuksel Keles (iD https://orcid.org/0000-0001-8651-8385

\section{REFERENCES}

Agati, G., Brinetti C., Ferdinando M.D., Ferrini F., Pollastri S., \& Tattini M. (2013). Functional Roles of Flavonoids in Photoprotection: New Evidence, Lessons from the Past. Plant Physiol. Biochem., 72(1), 35-45. https://doi.org/10.1016/j.plaphy.2013.03.014

Akman, Y. (2010). İklim ve Biyoiklim. Palme Yayıncilık. 345 s. Ankara. ISBN No: 9786054414468

Anacker, B.L. (2014). The Nature of Serpentine Endemism. Am. J. Bot., 101(2), 219-224. https://doi.org/10.3732/ajb.1300349

Arnold, B.J., Lahner, B., DaCosta, J.M., Weisman, C.M., Hollister, J.D., Salt, D.E., Bomblies, K. \& Yant, L. (2016). Borrowed Alleles and Convergence in Serpentine Adaptation. PNAS, 113(29), 8320-8325. https://doi.org/10.1073/pnas.1600405113

Avcı, M. (2005). Diversity and Endemism in Turkey's Vegetation. İÜ. Ed. Fak. Coğrafya Dergisi, 13(1), 27-55.

Batra, N.G., Sharma, V., \& Kumari, N. (2014). Drought-induced Changes in Chlorophyll Fluorescence, Photosynthetic Pigments, and Thylakoid Membrane Proteins of Vigna radiata. J. Plant Interact., 9(1), 712-721. https://doi.org/10.1080/17429145.2014.905801

Brady, K.U., Kruckeberg, A.R., \& Bradshaw, H.D. (2005). Evolutionary ecology of plant adaptation to serpentine soils. Annu. Rev. Ecol. Evol. Syst., 36(1), 243-266. https://doi.org/10.1146/annurev.ecolsys.35.021103.105730

Cai, Y., Luo, Q., Sun, M., \& Corke, H. (2004). Antioxidant Activity and Phenolic Compounds of 112 Traditional Chinese Medicinal Plants Associated with Anticancer. Life Sci., 74(17), 2157-2184. https://doi.org/10.1016/j.lfs.2003.09.047

Caponio, F., Alloggio, V., \& Gomes, T. (1999). Phenolic compounds of virgin olive oil: influence of paste preparation techniques. Food Chem., 64(2), 203-209. https://doi.org/10.1016/S0308-8146(98)00146-0

Çekiç, F.Ö., Özdeniz, E., Öktem, M., Kurt, L., \& Keleş, Y. (2018). The Role of Biochemical Regulation on the Adaptation of Gypsophile and Gypsovag Species. Biochem. Syst. Ecol., 81(1), 12-16. https://doi.org/10.1016/j.bse.2018.09.007 
Cheynier, V., Comte, G., Davies, K.M., Lattanzio, V., \& Martens, S. (2013). Plant phenolics: Recent Advances on Their Biosynthesis, Genetics, and Ecophysiology. Plant Physiol. Biochem., 72(1), 1-20. https://doi.org/10.1016/j.plaphy.2013.05.009

Chishaki, N., \& Horiguchi, T. (1997). Responses of Secondary Metabolism in Plants to Nutrient Deficiency, Soil. Sci. Plant Nutr., 43(sup1), 987-991.

https://doi.org/10.1080/00380768.1997.11863704

Choudhury, N., \& Behera, R. (2001). Photoinhibition of Photosynthesis: Role of Carotenoids in Photoprotection of Chloroplast Constituents. Photosynthetica, 39(4), 481-488. https://doi.org/10.1023/A:1015647708360

Davis, P.H. (1965). Flora of Turkey and The East Agean Islands, Vol.1, dinburgh Univ. Press. Davis, P.H. (1975). Flora of Turkey and The East Agean Islands, Vol.5 Edinburgh Univ. Press. Davis, P.H. (1982). Flora of Turkey and The East Agean Islands, Vol.7, Edinburgh Univ. Press. Gülcemal, D., Alankuş-Çalıskan, Ö., Karaalp, C., Örs, A.U., Ballar, P., \& Bedir, E. (2010) Phenolic Glycosides with Antiproteasomal Activity from Centaurea urvillei DC. subsp. urvillei. Carbohydrate Res., 345(17), 2529-2533.

https://doi.org/10.1016/j.carres.2010.09.002

Guo-Xiong H., Takano, A., Drew, B.T., Liu, E-D., Soltis, D.E., Soltis, P.S., Peng, H., \& Xiang, C.L. (2018). Phylogeny and Staminal Evolution of Salvia (Lamiaceae, Nepetoideae) in East Asia, Annals Bot., 122(4), 649-668.https://doi.org/10.1093/aob/mcy104

Harrison, S.P., \& Rajakaruna, N. (2011). Serpentine: Evolution and Ecology in a Model System. Rhodora, 113(956), 523-526. https://doi.org/10.3119/0035-4902-113.956.523

Keleş, Y., \& Öncel, I. (2002). Response of Antioxidative Defence System to Temperature and Water Stress Combinations in Wheat Seedlings. Plant Sci., 163(4), 783-790. https://doi.org/10.1016/S0168-9452(02)00213-3

Kim, D.O., \& Lee, C.Y. (2004). Comprehensive Study on Vitamin C Equivalent Antioxidant Capacity (VCEAC) of Various Polyphenolics in Scavenging a Free Radical and Its Structural Relationship. Crit. Rev. Food. Sci. Nutr., 44(4), 253-273. https://doi.org/10.1080/10408690490464960

Kruckeberg, A.R. (1951). Intraspecific Variability in the Response of Certain Native Plant Species to Serpentine Soil. Am J Bot., 38(1), 408-419.

Kurt, L., Ozbey, B.G., Kurt, F., Ozdeniz, E., \& Bolukbasi, A. (2013). Serpentine Flora of Turkey. Biological Diversity Conservation, 6(1), 134-152.

Li, Y., Kong, Y., Zhang, Z., Yin, Y., Liu, B., Lv, G., \& Wang, X. (2014). Phylogeny and Biogeography of Alyssum (Brassicaceae) Based on Nuclear Ribosomal ITS DNA Sequences. J. Genetics, 93(2), 313-323. https://doi.org/10.1007/s12041-014-0362-3

Moore T.C. (1974). Research Experiences in Plant Physiology. Springer-Verlag, New-York.

Nagaresh, K., \& Rahiminejad, M.R. (2018). A Revision of Centaurea sect. Cynaroides (Asteraceae, Cardueae-Centaureinae). Phytotaxa, 363(1), 1-131. https://doi.org/10.11646/phytotaxa.363.1.1

Öncel, I., Keles Y., \& Üstün, A.S. (2000). Interactive Effects of Temperature and Heavy Metal Stress on the Growth and Some Biochemical Compounds in Wheat Seedlings, Environ. Pollut., 107(3), 315 -320. https://doi.org/10.1016/s0269-7491(99)00177-3

Oncel, I., Yurdakulol E., Keles Y., Kurt L., \& Yildız A. (2004). Role of Oxidative Defense System and Biochemical Adaptation on Stress Tolerance of High Mountain and Steppe Plants. Acta Oecol., 26(3), 211-218. https://doi.org/10.1016/j.actao.2004.04.004

Özbey, B.G, Özdeniz, E., Bolukbaşı, A., Öktem, M., Keleş, Y., \& Kurt, L. (2017). The Role of Free Proline and Soluble Carbonhydrates in Serpentine Stress on Some Serpetinophyte and Serpentinovag Plants. Acta Biol Turcica, 30(4), 146-151.

Petukhov, A.S., Khritokhin, N.A., Petukhova, G.A., \& Kremleva, T.A. (2019). Phenolic Plant Defense System Under Conditions of Environment Pollution by Heavy Metals in 
Tyumen. Uchenye Zapiski Kazanskogo Universiteta. Seriya Estestvennye Nauki, 161(1), 93-107. (In Russian). https://doi.org/10.26907/2542-064X. 2019.1.93107

Porra, R.J., Thompson, W.A., \& Kriedemann, P.E. (1989). Determination of Accurate Extinction Coefficients and Simultaneous Equations for Assaying Chlorophylls a and $b$ Extracted with Four Different Solvents: Verification of the Concentration of Chlorophyll Standards by Atomic Absorption Spectroscopy. Biochem. Biophys. Acta, 975(3), 384394. https://doi.org/10.1016/S0005-2728(89)80347-0

Ramel, F., Birtic, S., Cuiné, S., Triantaphylidès, C., Ravanat, J.L., \& Havaux, M. (2012). Chemical Quenching of Singlet Oxygen by Carotenoids in Plants. Plant Physiol., 158(3), 1267-1278. https://doi.org/10.1104/pp.111.182394

Ruamrungsri, S., Ohyama, T., Konno, T., \& Ikarashi, T. (1996). Deficiency of N, P, K, Ca, Mg, or Fe Mineral Nutrients in Narcissus cv. "Garden Giant”. Soil Sci. Plant Nutr., 42(4), 809820. https://doi.org/ 10.1080/00380768.1996.10416628

Sağır, C., Everest, Z.A., \& Keleş, Y. (2018). The Comparative Investigation of the Antioxidant Activities of Some Species Belonging to the Lamiaceae and Poaceae Families. Anatolian J. Bot., 2(2), 52-59. https://doi.org/10.30616/ajb.397590

Sharmila, P., \& Pardha Saradhi, P. (2002). Proline Accumulation in Heavy Metal Stressed Plants: An Adaptive Strategy. In: Prasad M.N.V., Strzałka K. (eds) Physiology and Biochemistry of Metal Toxicity and Tolerance in Plants. pp, 179-199 Springer, Dordrecht. Printed ISBN: 978-90-481-5952-9, Online ISBN: 978-94-017-2660-3 https://doi.org/10.1007/978-94-017-2660-3_7

Wojdylo, A., Oszmianski, J., \& Czemerys, R. (2007). Antioxidant Activity and Phenolic Compounds in 32 Selected Herbs. Food Chem., 105(3), 940-949.

https://doi.org/10.1016/j.foodchem.2007.04.038 